Brit. F. vener. Dis. (1972) 48, 553

\title{
Obituary
}

\section{Gerald Legh Malins McElligott, M.A. Oxon., M.R.C.S., 1897-1972}

Dr. G. L. M. McElligott, Consulting Venereologist to St. Mary's Hospital, London, died on September 8, 1972. He was born in 1897 in Belper, Derbyshire, where his father was a general practitioner, moving shortly afterwards to Wigan. He was educated at Stoneyhurst College, and left school at the age of 17 at the outbreak of the first world war, when he joined the Munster Fusiliers, served in France, was wounded, and declared unfit for further service there; at one time he was the youngest captain in the British Army. After his service in France he was seconded to the Gold Coast Regiment (West African Frontier Force) and served in West Africa until the war ended when he joined the Colonial Service as a District Commissioner for about a year. In 1920 he went up to Oxford (Hertford College) and graduated B.A. in 1923, and then on to St. Thomas' Hospital where he qualified in 1926. He then practised in Rapallo, Italy, for a short time, went round the world as a ship's doctor, and returned to St. Thomas' to study venereology under Colonel L. W. Harrison. From there he took the post of Medical Officer to the Stoke-on-Trent Venereal Disease Clinic, until he was appointed in 1932 as the first Consultant Venereologist to St. Mary's Hospital; there he took over a clinic which had been run by the junior surgical staff in their spare time and had turned it into a first class one by the time the second world war broke out.

In 1938 he had joined the R.A.F.V.R. and was called up for service in September, 1939. He was put in charge of the main R.A.F. infectious diseases hospital which included the V.D. clinic at Halton. His good knowledge of general medicine was invaluable in dealing with the severe cases of meningitis etc. which came under his care in 1939 and 1940. He then became senior specialist in venereology, which entailed travelling to Italy, India, and Africa, rose to the rank of Air Commodore, and remained a consultant to the R.A.F. after the war until 1959. In 1945 he returned to St. Mary's and finding the volume of work there had increased greatly he extended it to a full-time clinic, which soon became the largest in the country as far as numbers of patients went. When Colonel Harrison retired as Adviser in Venereology to the Ministry of Health, McElligott took his place, and he himself retired from St. Mary's Hospital and the Ministry in 1959.

He went to live in the country, in Co. Wicklow, Eire, continuing his interest in medicine by doing locums at the Dublin V.D. Clinic and sitting on the Board of a children's hospital. Later he moved to his last home nearer to Dublin. In May 1971 he chaired the V.D. section of the Nineteenth British Congress of Obstetrics and Gynaecology with great success and much of his old energy.

'Mac' was a delightful companion with wide interests in many fields outside medicine and a seemingly endless fund of amusing stories, mostly about Ireland and his experiences in the Services. $\mathrm{He}$ had an extensive and detailed knowledge of the venereal diseases, especially syphilis, and was a very careful and dedicated doctor who would spare no effort in looking after a sick person, as well as being an enthusiast and a good teacher with that rare gift of passing on his enthusiasm to others. His organization of the routine of the old clinic at St. Mary's has been much admired and has been largely incorporated into the new one. He wrote the very best English, and his papers and chapters in text books were well worth reading, both for their content and presentation. He used to describe venereology as a 'summation of small skills'. His appointment at St. Mary's was made against considerable opposition from some members of the staff who were unwilling to recognize venereology as a separate specialty, but by the time he left he was accepted as an equal by all and his own standing and that of his clinic was of the highest. $\mathrm{He}$ was one of those pioneers in this specialty to whom Venereology is greatly indebted for what good reputation it now has. He was one of the earliest members of the M.S.S.V.D., becoming President in 1954, and was an active member of the Council for many years. Dr. McElligott is survived by his wife.

F. F. G. Fefferiss 